\title{
Historical and translation discourse of Abay in the ethnopedagogic paradigm: features of Analy
}

\section{Discurso histórico y de traducción de Abay en el paradigma etnopedagógico: características de Analy}

\author{
Bigaysha Z. Akhmetova \\ Bigaysha@mail.ru \\ https://orcid.org/0000-0001-6442-9293 \\ PhD of Philology, Associate Professor, Department of Kazakh and Russian languages, \\ Saken Seifullin Kazakh Agrotechnical University, Nur-Sultan, Kazakhstan. \\ Fatima B. Sautieva \\ fbilan@mail.ru \\ https://orcid.org/0000-0001-6998-9169 \\ PhD of Pedagogy, Associate Professor of the Department of Pedagogy and Methods of \\ Primary Education, Ingush State University, Magas, Ingushetia. \\ Zarema M. Mamieva \\ Mamieva-1965@mail.ru \\ https://orcid.org/0000-0002-3097-0046 \\ Senior Lecturer of the Department of Foreign languages, Ingush State University, \\ Magas, Ingushetia. \\ Aitbibi Sultanovna Orazbayeva \\ aitbibi1970@mail.ru \\ https://orcid.org/0000-0002-5091-4703 \\ $\mathrm{PhD}$ in Philology, Associate Professor, \\ Akhmet Baitursynov Kostanay Regional University, Kazakhstan. \\ Yulia V. Islamova \\ Y_Islamova@ugrasu.ru \\ https://orcid.org/0000-0003-3752-8418 \\ Candidate of Philology Science, Associate Professor of Russian Language and \\ Literature, Ugra Article University, Khanty-Mansiysk, Russia.
}

Recibido: 27/08/21

Aceptado: 1/11/21

\section{Abstract}

The article is devoted to the study of Abay's creativity as a historical precedent personality in the context of his ethnopedagogical, historical and translation discourses. Purpose of the work: identifying the essence of Abay's main discourses, analyzing them, determining the contribution of the precedent personality to the historical process of the formation of Historical and translation discourse of Abay in the ethnopedagogic paradigm: features of Analy. - Eduweb, 2021,
septiembre-diciembre, v.15, n.3. /82-101 
ethno-identity, as well as clarifying the degree of precedence of the personality and his texts. In the process of analysis, a complex method was used, based on the combination of discursive-historical, cognitive-discursive, and pragmatic-communicative approaches, the method of sociological survey. The results obtained include: description of Abay as a precedent historical personality, widely known for his legislative, social and political activities; a comprehensive analysis of the historical discourse of Abay, the discourse of biy (in Kazakh language), its extralinguistic, cognitive, pragmatic, linguo-stylistic components have been identified and described; the historical character of Abay's translation discourses is established, a comprehensive analysis of such a discourse is carried out, the precedent of the text of Abay's translations is noted. It is concluded that Abay Kunanbaev not only acted as an active historical person who managed to influence the actualization of historical events and their promotion, but also as a poet, translator, who created various discourses (historical, translation, literary). Abay's translation discourse acts as a kind of historical discourse - historical and literary discourse, since it has signs of historicity (created by a historical person, it reflects the features of the historical era). Therefore, these discourses can be analyzed based on a complex discursive-historical and cognitive-discursive approaches.

Key words: historical personality, historical discourse, translation discourse, ethnoidentity, social and political activity.

\section{Resumen}

El artículo está dedicado al estudio de la creatividad de Abay como personalidad precedente histórica en el contexto de sus discursos etnopedagógicos, históricos y de traducción. Objeto del trabajo: identificar la esencia de los principales discursos de Abay, analizarlos, determinar la contribución de la personalidad precedente al proceso histórico de formación de la etnoidentidad, así como aclarar el grado de precedencia de la personalidad y sus textos. En el proceso de análisis se utilizó un método complejo, basado en la combinación de enfoques discursivo-histórico, cognitivo-discursivo y pragmático-comunicativo, el método del relevamiento sociológico. Los resultados obtenidos incluyen: descripción de Abay como personalidad histórica precedente, ampliamente conocido por su actividad legislativa, social y política; se ha identificado y descrito un análisis exhaustivo del discurso histórico de Abay, el discurso de biy (en lengua kazaja), sus componentes extralingüísticos, cognitivos, pragmáticos, lingüísticoestilísticos; Se establece el carácter histórico de los discursos de traducción de Abay, se realiza un análisis exhaustivo de dicho discurso, se anota el precedente del texto de las traducciones de Abay. Se concluye que Abay Kunanbaev no solo actuó como un personaje histórico activo que logró incidir en la actualización de los hechos históricos y su promoción, sino también como poeta, traductor, que creó diversos discursos (histórico, traducción, literario). El discurso de la traducción de Abay actúa como una especie de discurso histórico: discurso histórico y literario, ya que tiene signos de historicidad (creado por un personaje histórico, refleja las características de la era 
histórica). Por tanto, estos discursos pueden analizarse a partir de enfoques discursivohistórico y cognitivo-discursivos complejos.

Palabras clave: personalidad histórica, discurso histórico, discurso de traducción, etnoidentidad, actividad social y política.

\section{Introduction}

Understanding the role of an individual in the historical process is one of the urgent problems of the country in the context of the formation of ethnoidentity. This is due, firstly, to the little-studied question of the importance of an individual in the history of the state. However, historical events are not predetermined, so the future has many alternatives and can change because of the activities of various groups and their leaders, it also depends on the actions of a variety of people, for example, scientists. Therefore, the problem of the role of the individual in history is relevant for each generation, especially in the age of globalization, when the influence of certain people on the whole world may increase.

Socio-cultural and ethnopedagogic matrices are mobile under the influence of aggressive external factors (Karabulatova et al., 2017), therefore, the growing interest in the problem of personality is explained by the formation of new paradigms of the functional and communicative direction in the XXI century (Sautieva et al., 2020; Vorozhbitova et al., 2019) of the anthropocentric paradigm of scientific knowledge (Savchuk et al., 2019).

To achieve the goal, it is assumed that the following tasks will be solved:

1) to consider the historical and translation discourse of Abay as a set of historical and translation texts, and to analyze their features in the aspect of the ethnopedagogic paradigm;

2) to find out the role of Abay in the history of the country and in the development of ethno-cultural pedagogical potential for Kazakhstan;

3) to find out the degree of precedent of the discursive personality of Abay and indicate the relationship with the cultures of other peoples with the definition of the layer of background knowledge marking the reference points of the formation of selfidentification of Kazakhs.

In modern conditions, ethnoidentity determines the vitality of an ethnos and a state, which is especially relevant in connection with the aggression of external factors of globalization, migration, the priority of electronic and digital communication, the pressure of the virtual environment, geopolitical problems of the preservation of states, in this regard, ethnopedagogy becomes the leading principle of preserving human civilization.

Kazakh educator, writer, composer Abay Kunanbayev is a passionate personality for the Kazakh state and people in the context of understanding their own identity and the place of Kazakhstan on the geopolitical map of the world. His work has not lost its relevance to this day. The study of the role of the discursive personality of Abay Kunanbayev as a Historical and translation discourse of Abay in the ethnopedagogic paradigm: features of Analy. - Eduweb, 2021,
septiembre-diciembre, v.15, n.3. /82-101 
precedent historical personality who made a significant contribution not only to literature, but also to the development of the historical process, as well as to the history of translation studies based on the study of his historical and literary discourse in the context of his historical epoch, is of considerable interest. Abay Kunanbayev, whose 175th anniversary was celebrated in 2020, acts as a precedent in the history of culture, whose works have become precedent, and his name itself is a symbol of Kazakh culture. The name " bai as a key sign contains a huge, informational cultural and historical potential. The proper name "Abay" can express not only linguistic knowledge, but also cultural, representing a linguistic and cultural sign that gives, on the one hand, linguistic, on the other - cultural, historical, social information (Karabulatova, 2013). Almost every locality in Kazakhstan has a street or avenue named after Abay, universities also bear his name, sweets "Abay", "Songs of Abay", collectible coins with the image of Abay, money with his portrait, etc. All this speaks about the colossal ethno-cultural potential of Abay's personality for the Kazakh culture.

We consider the context as "a complex phenomenon, consisting of several levels: linguistic context, intertextual, interdiscursivity levels, extra-linguistic level, socio-political and historical levels" (Budayev, 2016: 13).

An important principle of this approach is the integration of textual and socio-contextual levels of analysis of Precedent texts such person also has a high potential historic-cultural cross-cultural value, which is the core ethno-cultural potential of education.

\section{Materials and methods}

The purpose of our article is to identify the essence of the historical and literary (translation) discourses of Abay Kunanbayev, their analysis, to determine his contribution to the history of the country and the history of translation studies, to clarify the degree of precedent of the texts of the discursive personality, to determine the significance of A. Kunanbayev's creativity for the formation of positive ethnic identity of Kazakhs and the construction of Kazakh statehood.

Anthropocentrism is considered as such a methodological attitude, which is aimed at bringing to the fore the linguistic personality, studied in close connection with the language, the individual's consciousness, his thinking, spiritual and practical activity. The functional and communicative direction contributes to the study of human speech activity, focusing on the ways of expressing an assessment, a person's subjective attitude to what is being expressed.

The discursive paradigm promotes the study of discourse as a specific product of speech action with its inherent semantic uniformity, attachment to a certain context, genre, and ideological affiliation, as well as correlation with a whole layer of culture, social community and already with a specific historical period. 
B. B. Faul and T. S. Demin (2015), following T. A. van Dijk (1989), point out that this approach makes it possible to analyze how people use language, communicate, form groups, communities, demonstrating the diversity of cultures.

The merit of T. A. van Dijck is the emphasis on extralinguistic and linguistic factors in the analysis of discourse. Describing the discourse, the scientist pointed out that the discourse is "a complex communicative phenomenon that includes a social context that gives an idea of both the participants of communication, their characteristics, and the processes of production and perception of messages" (Dijk, 1989).

The main method of research is a discursive-historical analysis, it requires considering extralinguistic information (political, economic, cultural information) related to social problems, and focuses on the influence of ideology. Using this approach allows us to consider Abay as a historical person, to determine his contribution to the historical process as an ethnopedagogic progressor, to consider his socio-political views and educational ideas.

Along with this, the historical discourse of Abay is analyzed, because his views and ideas are reflected in them. The analysis of discourse involves both the study of the historical epoch in which the communicant lived, and the study of his mentality. Van Dijk (1989), focusing on the egocentricity of discourse, notes its extralinguistic nature, giving it the following definition: "speech flow, language in its constant movement, absorbing all the diversity of the historical era, individual and social characteristics of both the communicant and the communicative situation in which communication takes place. The discourse reflects the mentality and culture, both national and individual, private. This aspect is important for understanding the linguistic paradigm of Abay, which had a dominant influence on the formation of pedagogical thought in the Kazakh steppe. (Dijk, 1989; Vorozhbitova et al, 2019).

The discursive-historical approach proposed by R. Wodak and N. Fairclough involves the use of a three-dimensional model of analysis. N. Fairclough suggests analyzing the text, discursive practice, social practice. R. Wodak believes that the discursive-historical approach is carried out over three stages: 1) definition of the content and subject of the statement; 2) analysis of the discursive strategy of the text under consideration; 3) description of the "formal characteristics" (Wodak, 2009). These stages help us to understand the mechanism of formation of the accumulative function of Abay's ethnopedagogic strategies, to realize his work in the context of integration with European culture, which opened the opportunity for subsequent international communication.

The discursive-historical approach also involves the corpus of linguistic means, types of cognitive structures (knowledge, models, etc.) for the analysis of discursive units of the text.

Abay is considered as a linguistic personality capable of generating discourses in different languages and translating from one language to another. Therefore, in the field of view of 86 Historical and translation discourse of Abay in the ethnopedagogic paradigm: features of Analy. - Eduweb, 2021, 
the researcher is the characteristic of his ability to master different languages, as well as his translation discourse. For the analysis, the synergetic method is used, as well as its techniques (a method for determining the creativity of translations of a discursive personality based on the description of the reception of non-linearity of thinking, the reception of openness, cognitive development of the new). The method of transformational analysis is also used, a method of achieving the equivalence of the source and translated texts by using strategies of form and strategies of meaning.

\section{Discussion}

Ethno-pedagogical influence of Abay lies in the fact that he is not only the founder of the Kazakh literary language, but also created a methodology for teaching the Kazakh language. This activity of Abay became the starting point for further study of the Kazakh language and culture. Thanks to A. Kunanbayev, folk parables, tales, legends, proverbs, and sayings were included in textbooks on the Kazakh language and literature, history and culture of Kazakhstan. In addition, A. Kunanbayev contributed to the adaptation of the achievements of world literature in Kazakh society, creating transcriptions of Russian, German poets in the figurative system that was understandable for the common Kazakh people. Thanks to the literary and translation activities of A. Kunanbayev, the achievements of the world classics entered the linguistic consciousness of the Kazakhs. At the same time, A. Kunanbaev translated Kazakh folklore into Russian, promoting its popularization among ethnographers, folklorists, and teachers on the outskirts of the Russian Empire. Careful attitude to the monuments of folk art allowed A. Kunanbayev to become a symbol of Kazakh revival, a source of education of Kazakh ethnosocial and cultural self-awareness.

Abay's pedagogical views were formed under the conditions of the feudal-city system, distant from us by historical eras. However, the views of A. Kunanbaev are either very close or coincide with our views on very important aspects of pedagogical theories and practice: the relationship between labor moral, mental, aesthetic education, recognition of the leading role of education in the formation of personality, work as one of the main means of education and etc. Comprehension of his pedagogical views is impossible without studying the national origins of his work. Without understanding that he absorbed everything progressive that was in the life of the Kazakh people in their folk pedagogy and folk wisdom. This explains the fact that the national and international is relevant in the philosophical and pedagogical views of Abay (Zharikbaev, Kaliev, 1995). Problems affecting science and religion - he did not hesitate to take the side of science, i.e. I saw the future of the Kazakh people in mastering knowledge, developing education, science, enlightenment.

In accordance with his era and the requirements of life, Abay Kunanbayev called on Kazakhs who did not send their children to school, persistently advised to teach their children the Russian language "If you want your son to become a man, teach him, you will do the good for him and your people." ... He called on young people to learn, to master 
Russian science. Various new crafts, advised to work honestly for the good of society. Abay Kunanbayev in his work "The Book of Words, the Twenty-fifth Word", devoted to the disclosure of the decisive role of Russian education for the progress of the Kazakh people. He told his people: "The main thing is to learn Russian science. Science, knowledge, prosperity, art - all this is in the hands of the Russians" (Abay, 2020).

Abay was not a professional teacher. However, the value of his statements in this regard is beyond doubt for us. Where did Abay get all this wisdom from? He himself studied all his life, which is why he was able to evaluate his knowledge and never remained satisfied with the knowledge. According to Abai's eyes, children are drawn to study, their knowledge is formed gradually, when they realize the benefits of studying. He attached great importance to the fact that a person himself should strive for this, it pushes his mind, to the consciousness of the need for knowledge. Abay, at the same time, emphasized the importance of schooling Kazakh children in their native language. According to Abay, a person must master the basics of knowledge in his native language and only then he must move on to learning other languages. Pointedly and broadly raised the issue of universal public education: "We need to create a school, we need the population to provide funds for these schools, we need everyone to study, even girls" (Abay, 2020: 118).

The attitude to ethno-oriented learning in the works of $A$. Kunanbayev is considered in the article by Asankulova and Kalymbetova (2014), in which the authors emphasize the importance of A. Kunanbayev's activities to popularize the promotion of the Kazakh language in the Steppe Territory.

Bold statements about the need for enlightenment were expressed by A. Kunanbaev, who creatively reworked all the valuable thoughts on the issues of training and education of the younger generation of thinkers of previous eras. Following Pythagoras and Aristotle, al-Farabi, Davani Abay strongly opposed corporal punishment of children. In his didactic instructions, he noted that the main principle of teaching is from simple to complex, while it is necessary to consider the age characteristics of children (Abay, 2020). He argued that teaching should be carried out in the native language of students, since the goal of ethno-oriented education is to develop students' ability to think independently, to constantly maintain an interest in learning (Saitkasimkhanova, 2008; Aipova et al., 2021). Inoculating young people to master the foundations of science, A. Kunanbaev shows the ways to solve this problem. And here the educator deals with the issues of self-education of the individual. Recognizing to love a person, to love beauty, Abay considers the aesthetic in an inextricable connection with the ethical (Uspanova, 2002). A person achieves happiness under the condition of the all-round and holistic development of his personality, combining the sharpness and depth of reason, nobility of heart and unyielding will. He was a passionate preacher and tireless champion of the moral education of youth, being one of the founders of Kazakh scientific thought in the field of education and upbringing.

Since the representatives of the tsarist administration did not speak the Kazakh language (Sturova, 2012), Abay published his enlightening thoughts not only in Kazakh, but also in Historical and translation discourse of Abay in the ethnopedagogic paradigm: features of Analy. - Eduweb, 2021,
septiembre-diciembre, v.15, n.3. /82-101 
Russian, to help the local administration, understand the specifics of the ethnic selfknowledge of the Kazakhs. Comprehension of Abay's pedagogical views is impossible without studying the national origins of his work, without understanding that Abay absorbed everything progressive that was in the life of the Kazakh people themselves, in their folk pedagogy, folk wisdom (Sautieva et al., 2021). This explains the fact that in the philosophical and pedagogical views of Abay, the national and international are not opposed, but act in unity as interrelated and complementary ideas. The same can be said about his coverage of the issues of the relationship between the cultures of the Kazakh and other peoples.

It is known that Abay was not a person completely free from religious views. When the question arose - science or religion? - he took the side of science without hesitation. Apparently, this circumstance decisively influenced his assessment of religious education, which he resolutely rejected as reactionary. He advocated secular education and upbringing, liberating, and developing the mind, forming human dignity in the child.

Based on the study of the works of progressive teachers and the national experience of folk pedagogy, the pedagogical views of the thinker corresponded to the level of development of contemporary science, and in many cases even outstripped it (Abisheva et al., 2020).

The problem of studying a linguistic multilingual personality as a discursive one relates to the possibility of a personality to generate discourses of different types (Karabulatova et al, 2017). By a discursive personality, S. N. Plotnikova understands a linguistic personality, "which generates a certain discourse in the form of a message and is responsible for its content" (Plotnikova, 2008). We consider Abay as a multilingual person who can generate various types of discourses (historical and translation), who has a huge ethno-pedagogical potential of influence both during his life and at the present time. At the same time, we characterize him as a "people's diplomat" who ensured the entry of the Kazakh Steppe into the international cultural space by creating translated texts of classics of Russia and Europe. Therefore, we can say that Abay is also a precedent person, whose name and texts are widely known not only in Kazakhstan, but also abroad. Russian actively used the traditional background knowledge of Kazakhs to convey similar cultural meanings of Russians and Europeans, providing " an ethno-cultural dialogue between the Kazakh Steppe and the Russian Forest (Karabulatova, Koyshe, Gultyaev, 2013: 853).

The attribution of Abay to historical figures is because his activities had a significant impact on the course of history. According to the classification of S. Hook, there are: 1) historical figures who influence events; 2) people who create events (Hook, 1955). Abay can be attributed to people who both influence events and create events. The creation of historical events by him relates to his activities as a biy and a volost administrator. In the report of Major-General Galkin on August 25, 1903, addressed to the military governor, it was said about Abay that " he is a very developed and intelligent person, he served for 2 three years as a biy and 3 three years as a governor of the Chingiz 
parish, then he served for one three-year as a governor of the Nukur parish by appointment from the government. Kunanbayev's service was distinguished by reasonable efficiency and energy, loyalty to the government and lack of fanaticism (Kunanbayev, 1995: 133).

Kazakhs got acquainted with the Russian classics, according to S. Abdrakhmanov's fair remark, thanks to Abay's translations. Abay considered the priority of oral transmission of knowledge and folklore in the Kazakh culture, so his translations were organically integrated into the traditional paradigm of Kazakh folklore, introducing the plot outline of the novel "Eugene Onegin". The ethnopedagogical potential of A. Kunanbayev also consisted in the use of the ethno-cultural component as a unified development system a multilingual personality: teaching, upbringing by means of native culture and the culture of the Russian language. The Russian language acted as a translator of European culture, through Kazakh translations of German romantics, Abay introduced the Kazakh steppe to the cultural achievements of poetic Europe. We understand that by forming a cultural environment, the potential of a creative, intellectually developed personality is being realized. Abay tried to bring to the heart of every ordinary Kazakh the main motives, the innovative spirit of Pushkin's novel, the most important for the Kazakh society of that historical period (Abdrakhmanov, 2008: 179). At the same time, Abay uses the background knowledge of the Kazakh culture. Russian and Kazakh culture share common ground with this knowledge, which made it possible to eliminate the ethnic and socio-cultural distance between Russians and Kazakhs in the future.

In the interpretation of A. Kodar (2008), the philosophical prose, or philosophical discourse of Abay has:

1. Direct analogs in the west -European philosophical tradition associated with the names of Montaigne, Schopenhauer, Kierkegaard, Marcus Aurelius, Blessed Augustine; before Abai, this tradition is Western -European philosophizing reached presumably through L.N. Tolstoy (Abdildin, Abdildina, 2015);

2. Abai, seized by progressive trends of the XIX century, it was closely within the framework of Muslim orthodoxy and, therefore, in in search of form, he turns to an essayistic manner of writing, free and uninhibited, where you can think about anything and in any direction (Fazilova, 2016).

The popularity of A. Kunanbayev's ideas lies in his mythopoetics, since they are based on Sufism and pagan views of the Kazakh people (Martazanov et al., 2021; Sautieva, 2003), therefore, the work of the enlightener is a conversation with himself and with God, that is, it is lonely thinking aloud, or monologues, as they are called in the Western European tradition; let us recall the "Monologues" of Augustine or "Reflections" of Marcus Aurelius, which appeared in a situation similar to Abay- a situation of self-exclusion from the crowd in order to strengthen one's faith and thought, which has become for them above all else. 
Abay went down in history as the creator of Kazakh writing and the founder of Kazakh philosophy because he played the role of Socrates for nomadic Kazakhs, who shattered the canons of traditional thinking and put them on the path of thought and faith with an imperious hand. Simultaneously, in his works, Abay created a model of behavior, which is still a model for posterity; it is a model in which culture and civilization, religion and philosophy, people and humanity are created.

Noting the merits of the analysis of A. Kunanbayev's legacy, we can note that they do not give a holistic picture of the discursive space of Abay's personality. In addition, we would like to separately note that Abay's "Edifications" are actively used at the present time as a guide to create matrices of ethnosocial and civic identity (Lin et al., 2021; Karabulatova et al., 2021) in Kazakhstan, which indicates a high modeling ethnopedagogical potential (Savchuk et al., 2019) of a researcher, a scientist, and a poet.

As a result of the conducted research, we carried out a comprehensive analysis of the discourses of Abay as a powerful ethno-cultural personality, widely known as a historical, as well as literary and translation personality. During the analysis, it was proved that Abay is a historical figure who made an important contribution to the formation of the ethnic consciousness of the Kazakh people, thanks to his legislative, socio-political, and literary activities. It was established that Abay is the author of the Code of Laws of the Kazakh Customary Law, in which there were 94 provisions. Abay has repeatedly served as a judge, took part in socio-political and educational work. Abay tirelessly fought against the bureaucratic authorities, with local basis who oppressed the people. For this, he was persecuted for 9 years. His letter to the Governing Senate is known.

Abay's ideas are characterized as humanistic. All his ideas, socio-political views were reflected in his historical discourse. The signs of historical discourse are revealed, the Biysk discourse of Abay is considered and its discursive analysis is carried out based on complex discursive-historical and cognitive-discursive approaches. The results of our article are obtained while studying historical discourses of different types (biy's discourse and the translation discourse of the same person). In contrast to the results of other authors we carried out a discourse analysis of different statements of one historical person because of an integrated approach. The obtained results can be explained by the fact that during the analysis of different types of discourses, methods of analyzing historical discourse were used (the method of considering the typology of historical discourses, the method of considering the features of historical discourse). The translation discourse was considered as historical, considering the time of translation (1888), considering the presence of signs of a historical epoch in the translation text.

The results of the conducted research can be applied during the analysis of discourses of different types based on an integrated approach (a combination of discursive-historical and cognitive-discursive approaches). 
Thus, the analysis of Abay's discourses shows that they can be characterized as historical and historical-literary (translation). The author of them is characterized as a historical person who has made a certain contribution to the history of the country: the development of the provisions of the legal code, the occupation of the biy and volost for several years, socio-political activities (the fight against the bay, the authorities, the protection of the common people). The analysis of his biy discourse contains such features of historical discourse as: 1) taking into account the social context, i.e. a brief description of the historical era of the implementation of this discourse; the national features of the Kazakh court under customary law are considered; 2) discursive means (linguistic lexical units, grammatical means characteristic of the language of the second half of the XIX centurylegal terms (sheshim, baylau, zhesir dauy, kun) figurative means (metaphors, epithets) are analyzed; knowledge concerning the girl's kalym, the custom of matchmaking, the custom of amangery, knowledge about kalym, barymty); 4) a pragmatic-discursive approach has also been implemented, which allows us to present the discourse of biy as a set of speech acts: representatives, declaratives, verdictives. Such a discourse of biy gives an idea of the historical epoch, the mentality and customs of that period, the peculiarities of the Kazakh court, the specifics of lexical and grammatical means of historical time.

Abay's ethno-cultural competence, the ability to see his own ethnosociostereotypes are professionally important qualities of him as a teacher, educator in the Kazakh Steppe at the stage of forming his own statehood and awareness of his own identity.

\section{Results}

The ethnopedagogic potential of Abay for the formation of the entire Kazakh nation lies in the fact that Abai developed one of the first legal documents in the Kazakh language. Abay was one of the first to introduce the Kazakh language into the official business sphere of the administrative policy of imperial Russia, thereby initiating the creation of a full-fledged literary Kazakh language. This document has been preserved in the archives (Kunanbayev, 1995: 62-63). S. F. Udartsev claimed that it was Abay who developed the document submitted to the congress. The document was drawn up so competently and clearly that this prepared normative act, consisting of 93 articles (paragraphs), which was unanimously approved by those present (Udartsev, 2007). This document was also called in another way "The Code of Ordinary Kazakhs". The original document was kept for 134 years in Kazan, in the museum of the Kazan Lobachevsky University (Internet-magazin Zona-KZ, 2019).

According to A. N. Taukelev, "The Trial of Karamol" was an attempt to bring together the laws of the steppe and the laws of the Russian Empire. Abai was the first in Kazakh jurisprudence to introduce punishment for contempt of court. It was in 1885 that the concept of an oath for giving false testimony appeared. Abai also considered the procedure for electing biys. The concept of a statement of challenge to a judge, etc., is introduced (Taukelev, 1960). 
The cognitive approach in Abai's speeches demonstrated knowledge about the folk customs of the historical period when a girl was paid for kalym, about the ancient custom of marrying a girl whose fiancé died for her close relative, about fines paid by the opposing party to the injured party, about the custom of barymty-cattle theft, etc.

The discourse of Abay as a biy (judge) gives an idea of his personality, views, knowledge, historical epoch, as well as the lexical, grammatical, and stylistic means used to promote the expressiveness of his speech.

The attribution of Abay's translations to the historical and translation discourse is due, firstly, to their belonging to a certain historical epoch; secondly, to the fact that Abay's translation texts note innovative traditions that contributed to the development of translation studies in Kazakhstan. The empirical basis in this study is the translations of the poems of M. Yu. Lermontov, A. S. Pushkin "The Letter of Tatiana", "The Letter of Onegin", etc. Historical and discursive translation analysis of them allows us to reveal both information about the views and mentality of the heroes, as well as the conditions for translating the Russian text into the Kazakh language, information about the innovative strategies of Abay-translator. This approach is combined with a cognitive-discursive analysis of the translation text, which helps to identify knowledge about the national characters of the heroes of the source text and the translation text, methods of equivalent transmission of the original text.

In the eighties of the XIX century, Abay closely communicated with exiles resettled in Kazakhstan. They were E. G. Michaelis, S. S. Gross, A. A. Leontiev, N. Dolgopolov. The exiles helped Abay to get acquainted with Russian literature. Abay himself at this time engaged in literary activities and translations. He is actively engaged in socio-political activities (preparing Heresy, working as a full member of the Semipalatinsk statistical committee, conducting research on the history of Kazakh clans, on the history of ordinary Kazakh law). Abay, when translating "Tatiana's Letter", tried first of all to bring to the Kazakh reader the image of Tatiana in the interpretation of the image of a Kazakh girl, i.e. instead of the Russian Tatiana in the translation, we see the image of a Kazakh girl, tender, passionately loving, devoted to her feelings.

Abay transmitted "Eugene Onegin" in the form of letters in verse. The fact is that in the era of Kunanbayev, love correspondence between boys and girls became a tradition in the Kazakh aul. Moreover, these letters, as a rule, were written in poetry, and all this had a peculiar romantic character. Thus, Abay correctly groped the request of his reader.

And here's another touch of the Kazakh genius's talent for translation. Remember from Pushkin, Tatyana asks Eugene:

Though rarely, even once a week In our village to see you. 
For his people, Abay translates as follows: "Shydar eem kuyip men zhanyp, / Aiyna berer kursem de" ("Even burning with impatience, I would have endured everything / If I had to see you at least once a month"). Why more than once a week, ask? But because the poet addresses his work to the youth of the Kazakh aul. The steppe is not a village. In the Russian countryside, people get together at least once a week to pray in church. In the vast steppe space, people are also happy when they meet at least once a month. And a guy and a girl see each other very rarely, for fear of unwanted rumors and misinterpretations. It is also appropriate to mention here that the Kazakhs, when they met in the steppe, asked each other in detail about life and life, about the health of family members and relatives, about the safety of livestock, and so on, apparently knowing in advance that the next meeting would not be soon ... At least until the advent of the mobile phone, this was the case.

The artistic scale of the poetic translation of Abay Kunanbayev is clearly manifested in the translations of poems by Mikhail Lermontov. And here again we see how the Kazakh poet literally lives the images of the Russian poet. Let us recall the lines familiar from childhood:

Mountain peaks

Sleep in the darkness of the night

Quiet valleys

Full of fresh haze.

The Abay's genius reduces Lermontov's "mountain peaks" to the designation of ordinary "mountains" (approximately to the Chinggis mountains, which do not have transcendental peaks), and transforms the "valleys" into wide "steppes" (like, say, Karaul), so Goethe's picture easily moved to Kazakh land. Comparing the three options at the same time, we can note that the night, which makes the steppe not only quiet, but also indifferently exhausted, occurs only on these wide-open spaces, only on the Kazakh land. We must say that Abay the translator felt his closeness to the work of M. Lermontov. Abay translated into the Kazakh language such famous masterpieces of M. Lermontov as "Borodino", "I go out on the road alone", "Duma", "Dagger", "Prayer", "Gifts of Terek" and much more. Abay treated Lermontov's poetry with special trepidation, feeling a spiritual kinship with him. It would not be an exaggeration to say that, imbued with sympathy for Russian poetry, Abay found the greatest spiritual consonance in Lermontov. By that time, Abay was already at the level of a comprehensive understanding of the intellectual world, the needs, the fate of not only the great poet, but the entire Russian society. Therefore, he perfectly understood the poetry of this people. I felt perfectly well that Lermontov's indignation, sadness, and anger expressed indignation, anger and sadness of the Russian people, the exploited society. Abay transposed most of Lermontov's poems in the form of a clean translation, and when he dealt with Pushkin, he allowed more freedom, allowed himself to interpret the details in his own way, to change the characters, moral traits of the characters in his own way. In other words, if Abay speaks with Pushkin in competition, then with Lermontov - in agreement. 
According to M. M. Myrzakhmetuly, at one time Abay set a goal - to teach Kazakh youth to evaluate the depth and weight of this feeling of love through the image of Tatiana (Myrzakhmetuly, 1997: 155). In the process of translation, Abay subtly considers the nature of the Kazakh worldview. In her translation, Tatiana's words "At least rarely, at least once a week // In our village to see you" Abay says that Kazakh guys and girls rarely see each other, months pass while the villages roam nearby, so people are always happy to meet. And a guy and a girl rarely meet, for fear of gossip, gossip.

It can be argued that before the appearance of translated samples, the Kazakhs were alien to the fable as a separate literary genre (note that before Krylov, the fable was not widespread in Russian literature either). In the 19th century, Kazakh children did not want to read fables, if they did, they laughed at them, and their parents were completely offended that, they say, they were teaching their children such nonsense, as if a magpie and a crow were talking among themselves. Translation of fables by Ivan Krylov was one of the important milestones in the development of not only the Kazakh translation art, but in general the entire Kazakh literature, as well as ethno-oriented pedagogy.

The fact is that Abai translated the Krylov's fables with such a national flavor that it is incorrect to consider them as a simple rhymed version of the translation. Let's be frank: after all, for example, Krylov's fable "The Dragonfly and the Ant" is not considered a translation from the French of the great Jean de La Fontaine (and even deeper - from the ancient Greek language in which Aesop wrote)? Why should the Abaevsky fable be considered Krylov's translation? A scrupulous analysis of this fable proves that we can quite put this work on a par with Abai's own works. The sound writing of the verse is striking, everything flows like that, the rhythm, rhyme, intonation, musicality of speech is impeccable. When we talk about the evolutionary path in translations of Krylov's fables, we first of all mean their non-nativeness for the Kazakh ear, comprehensibility, transmission in a figurative and juicy language, then - adaptation to steppe life.

Let's give just one example. In Abay, the heroine of the fable is not the Dragonfly, but the Grasshopper (Shegirtke), and therefore. Dragonfly - in Kazakh "inelik", from the word "ine" - a needle, thinness (in modern Kazakh language there is even an expression used for thin people - "ineliktey ilmiip"). Every Kazakh in the steppe knows that the dragonfly is thin and voiceless, which means that in the fable the phrase "Red Summer sang" in relation to the Dragonfly would sound out of tune. But the grasshopper can sing as much and quite loudly. It is curious that La Fontaine's fable is called "The Cicada and the Ant," and the cicada, as you know, is a distant relative of the grasshopper. But Krylov refused from Cicada, because at that time the Russian reader did not know this insect, and from Grasshopper, because this word is masculine, and in that case the fable would have consisted of a conversation between two "men" - Grasshopper and Ant. And Ivan Krylov needed a conversation between a neighbor and a neighbor. Abay, "correcting" Krylov, changing the Dragonfly to the Grasshopper (fortunately, the Kazakh language is not constrained by the generic framework) and transferring events from the forest to the steppe, thereby ultimately creating a real Kazakh fable. The fable left a special mark on 
the Kazakh national consciousness. The instructive translations that came out from the pen of Abay Kunanbayev over time had a positive impact on the process of writing their own Kazakh fables. It was through the fable that the written literature of the Kazakh people first met the best examples of world verbal art.

Identify the precedent of Abay's personality and his texts, a sociological survey was conducted based on questionnaires sent by e-mail. The questionnaire consists of four blocks:

1) appeal. It contains the motivation that encourages the respondent to cooperate;

2) demographic block: year of birth, gender, marital status, length of service, profession;

3) the main part is devoted to collecting and obtaining information about the precedent personality.

It includes twenty questions devoted to identifying respondents ' knowledge about Abay, his personality, knowledge about his texts, value-ideas, for example:

1. Do you consider Abay a historical figure?

2. What episodes, historical events relate to Abay's participation in the historical process?

3. Why does Abay act as a symbol of Kazakh culture?

4. What is the precedent of the proper name "Abay"?

5. What texts of Abay do you know?

6. What statements of Abay can you remember?

7. What value-concepts of Abay are important for culture?

8. Which poet did Abay translate the most?

9. What translations of it were widely known in the steppe in the second half of the XIX century?

10. What contribution did Abay make to the history of Kazakh and world culture? Etc.

The analysis of the questionnaires was carried out by applying the method of quantitative analysis. It was found that $80 \%$ of the subjects have an idea of Abay's personality, know his texts and can quote Abay's statements, excerpts from his works. All this contributed to the assertion of the position that Abay is a well-known precedent name, which is a compressed image that gives an idea of the values of a person, the culture of his people, the texts of a person remembered by the plot, characters, situations.

\section{Conclusion}

Creative approach to translation allowed Abay also use the strategy of associative thinking, when new images, associations, secondary associative connections of words began to appear on the basis of any word in the original. These new associative connections began to combine reality and create a kind of myth about it by emphasizing any knowledge about the properties of realities and dispositions. 
A. Kunanbayev used this non-standard approach both in translation and literature, and in pedagogy, jurisprudence and law, organically combining the constants of folk culture with the requirements of the time.

Based on the above, it is important to note that the mechanism of A. Kunanbayev's historical and translation discourse is to bring to the fore the individual characteristics of the concepts that convey information that is relevant in a particular ethnosociety. However, the analysis of the discursive practices of $A$. Kunanbayev makes it possible to restore the missing aspects for the formation of the concept by referring to the cognitive areas, such as: the mental space of the Kazakh language picture of the world, the conceptual structure of the Kazakh language. Consequently, the analyzed discourse of Abay can be presented as a conglomerate of linguistic and cognitive structures and as a cognitive mechanism.

Abay's discourse is subordinated to the cognitive organization, it can be characterized through the concept of mental space, understood as a collection of concepts; the way of structuring the concept determines the selection of linguistic means expressing the position of A. Kunanbayev.

Here the basic, constructive cognitive the unit of discourse is the concept as a mental formation, the nature of which is determined by the peculiarities of speech-thinking practice, focused on the social context.

Humanitarian forms of knowledge, understanding and criticism are in demand in a society where, according to forecasts, the human dimension can turn into a new form of luxury: against the background of the massive introduction of algorithms and artificial intelligence systems in various spheres of life, it is human assessment, human interaction, and human communication that may turn out to be a valuable resource in demand in the modern world.

Abay used the principles of folk pedagogy, in which there is a fairly clear differentiation of the main functions of ethno-didactic means: proverbs are used mainly for ethnic education, riddles for mental development, games for physical education, etc. Of course, each of the means, along with the main teaching function, it also has other functions. For example, there is a lot of logic and poetry in proverbs, beauty in riddles, intellectual and emotional charge in games, etc. A. Kunanbayev strengthened the ethnopedagogical element in school didactics, adding world and Russian classics in his own translations into Kazakh, adapting to Kazakh language picture of the world.

Abay understood that the poetic form of knowledge transfer, which dominated in Kazakh culture, has a multifunctional ethno-didactic character, the importance of which can hardly be overestimated not only in pedagogy, but also in human life. Folk oral transmission of knowledge exists in three dimensions: past, present, and future. The centuries-old experience of the people absorbed into the game belongs to the past; in the present - 
meeting the needs of a developing child; to the future - consolidation of the skills and abilities necessary for its formation as a person in order to prepare for life.

Songs, parables, fairy tales and fables are one of the richest treasures of the linguistic culture of the people. They combine both logical thought and poetic image. These genres teach and develop and educate. The simplicity of the language, its proximity to colloquial speech, the richness of images, the fascination of the plot allowed A. Kunanbayev to use these genres as a wonderful ethno-didactic tool.

To achieve success in the full development of a creative, spiritually rich humanistic personality, without which the construction of a civil society, a legal state is impossible, it is necessary to solve the problems of morality, spiritual culture of society, transfer to the young generation of creative experience, spirituality, religious culture, experience of an emotional-value attitude to the world.

The reason for many negative phenomena in recent years in the field of education was the violation of the three fundamental principles of pedagogy: continuity, nationality, and conformity to nature. A way out of this contradiction is possible in the use of ethnopedagogical principles in the education system, aimed at restoring the connection between times, revival, and creative use of the historical and pedagogical experience of peoples.

\section{Reference}

Abay. (2020). Book of words. Words of edification. Almaty: Almatykitap, 224 p. 978-60101-2990-0

Abdrakhmanov, S. (2008). Translation of poetry and poetry of translation. Astana: Audarma, $412 \mathrm{p}$.

Abdildin, J., \& Abdildina, R. (2015). Abay: a genius thinker and humanist. To the 170th anniversary of Abay. Astana: Foliant, 228, p. ISBN 978-601-302-288-8

Abisheva, K.M., Karimova, K.K., Kapanova, A.K. (2020). Abay as a linguocreative personality, translator. Neophilology, No. $21 . \quad$ URL: https://cyberleninka.ru/article/n/abay-kak-lingvokreativnaya-lichnost-translyator (date accessed: 09/27/2021).

Aipova, A., Apaeva, A., Temirgalinova, A., Shabambaeva, A., \& Karabulatova, I. (2021). The features of the formation of ethno-value consciousness in the modern Kazakh Pedagogical University. EduWEB. Revista de Tecnología de Información y Comunicación en Educación, 15(2), 229-244, DOI: https://doi.org/10.46502/issn.1856-7576/2021.15.02.18

Asankulova, B.S., \& Kalymbetova, N.P. (2014). Pedagogical heritage of the Kazakh enlighteners of the 19th century. Austrian Journal of Humanities and Social Sciences, No. 1-2. URL: https://cyberleninka.ru/article/n/pedagogicheskoenasledie-kazahskih-prosvetiteley-xix-veka (date of access: 09/27/2021). 
Baltabayeva, Z., Sautieva, F., Skorobogatova, A., \& Mamatelashvili, O. (2020). The impact of success factors on the strategic management in an educational complex. Amazonia Investiga, 9(29), 336-346. https://doi.org/10.34069/Al/2020.29.05.38

Budayev, E. V. (2016). Critical analysis of political discourse: the main directions of modern foreign research. Political Linguistics, No. 6, pp. 12-17.

Dijk van, T. A. (1989). Language. Cognition. Communication: M., pp. 112-115.

Faul, B. V., \& Demin, T. S. (2015). Teun van Dyck and modern discourse analysis. Philology and literary studies, No. 9 [Electronic resource]. URL: http://philology.snauka.ru/2015/09/1686 (accessed: 12.09.2020).

Fairclough, N. (2010). Critical Discourse Analysis: The Critical Study of Language. 2nd Edition, Routledge, 608 p. ISBN 9781405858229

Fazilova, K.B. (2016). Artistic features of the works of Abay Kunanbayev. Scientific journal, No. 6(7). URL: https://cyberleninka.ru/article/n/hudozhestvennyeosobennosti-proizvedeniy-abaya-kunanbaeva (date of access: 09/27/2021).

Hook, S. (1955). The Hero in History: A Study in Limitation and Possibility. Bostok: Beacon Press.

Internet-magazin Zona-KZ (2019). The Karamolinsky charter of Abay was found in Kazan [Electronic source]: https://zonakz.net/2019/06/13/karamolinskij-ustav-abayanashli-v-kazani/

Karabulatova, I.S. (2013). The problems of linguistic modeling of new Eurasian linguistic personality in multilinguistic and mental environment (by example of onomasphere). Middle-East Journal of Scientific Research 17 (6), 791-795, 2013. ISSN 1990-9233. (c) IDOSI Publications. DOI: 10.5829/idosi.mejsr.2013.17.06.12262.

Karabulatova, I.S., Koyche, K.K., \& Gultyaev, V.N. (2013). The Dialogue of Kazakh Steppe and Russian Forest: About the Character of Turkic-Speaking Linguistic Personality on the Territory of Russian-Kazakhstani Border-Zone. Middle-East Journal of Scientific Research, 17 (7), 853-858, ISSN 1990-9233. IDOSI Publications, 2013. DOI: 10.5829/idosi.mejsr.2013.17.07.12264

Karabulatova, I., Vildanov, Kh., Zinchenko, A., Vasilishina, E., \& Vassilenko, A. (2017). Problems of transformation matrices modern multicultural identity of the person in the variability of the discourse of identity Electronic Information Society. Pertanika Journal of Social Science \& Humanities, № 25(S), p.1-16.

Karabulatova, I.S., Lagutkina, M.D., Borodina, N.V., Streltsova, M.A., \& Bakhus, A.O. (2021). Formation of ethnosocial identity in the matrix of media discourse. Amazonia Investiga, 10(43), 234-247. https://doi.org/10.34069/Al/2021.43.07.23

Kodar, A.A. (2006). Call of Being. Almaty: Taimas, 527 p. ISBN 9965-806-15-2

Kunanbayev, A. (1995). Abay zhane archive (Abay and the archives). Almaty: Gylym. ISBN 5-628-01718-3 https://rusneb.ru/catalog/000200 000018 RU NLR BIBL A 012241523/

Lin, Y., Karabulatova, I.S., Shirobokov, A.N., Bakhus, A.O., \& Lobanova, E.N. (2021). Cognitive distortions in the reflection of civic identity in China: on the material of Russian-language media of East and Western. Amazonia Investiga, 10(44), 115-125. https://doi.org/10.34069/Al/2021.44.08.11 
Myrzakhmetuly, M. (1997). Auezov and Abay. Almaty, 406 p. ISBN: 978-601-04-3040-2 https://abaialemi.kz/post/view?id=417

Martazanov, A.M., Karabulatova, I.S., Martazanova, K.M., \& Sarbasheva, A.M. (2021). Sacred mythopetronym as a spiritual and moral value of the North Caucasian culture. Amazonia Investiga, 10(44), 103-114. https://doi.org/10.34069/Al/2021.44.08.10

Pinkovetskaia, I., Arbeláez-Campillo, D., Rojas-Bahamón, M., Novikov, S., \& Veas Iniesta, D. (2020). Social values of entrepreneurship in modern countries. Amazonialnvestiga, 9(28), 6-3. https://doi.org/10.34069/Al/2020.28.04.1

Plotnikova S. N. (2008). Linguistic, discursive, and communicative space. IGLU Bulletin. Ser.: Philology, No. 1, pp. 131-136. https://docplayer.com/51997712-S-nplotnikova-yazykovoe-diskursivnoe-i-kommunikativnoe-prostranstvo.html

Rojas-Bahamón, M.J., Aguilar-Cruz, P.J., \& Arbeláez-Campillo, D.F. (2020). Curricular integration as a strategy to strengthen the educational process in public institutions in COVID-19 times. Revista Inclusiones, 7 (num Especial), pp. 233-241.

Saitkasimkhanova, D.M. (2008). Pedagogical conditions of nature-oriented education of students by means of folk pedagogy: on the material of the Republic of Kazakhstan (Doctoral thesis, Ped. Acad. Postgraduate education) Pedagogical University of Southern Kazakhstan, $\quad$ Moscow, $27 \quad$ p. https://www.dissercat.com/content/pedagogicheskie-usloviyaprirodosoobraznogo-vospitaniya-obuchayushchikhsya-sredstvami-narodn

Sautieva, F. B., Radzhabov, I.M., Karabulatova, I.S., \& Pakhomenkova, O.M. (2021). Mythologization of inner space of the North Caucasus and folklore. EduWEB. Revista de Tecnología de Información y Comunicación en Educación, 15(2), p. 292-305. DOI: https://doi.org/10.46502/issn.1856-7576/2021.15.02.22

Sautieva, F.B. (2003). Peculiarities of teacher training for elementary public schools at pedagogical courses in Russia in the second half of the 19th and beginning of the 20th centuries (abstract dis. ... candidate of pedagogical sciences) Moscow State Pedagogical University, Moscow, $20 \quad$ p. https://www.dissercat.com/content/osobennosti-podgotovki-uchitelei-dlyanachalnoi-narodnoi-shkoly-na-pedagogicheskikh-kursakh-

Savchuk, I., Karabulatova, I., Golubtsov, S., Zelenskaya, V., \& Akhmetova, B. (2019). Language features of the legends genre as the basis of storytelling technology in advertising discourse. Amazonia Investiga, 8(21), 522-530. Retrieved from https://amazoniainvestiga.info/index.php/amazonia/article/view/132

Sturova, M.V. (2012). Educational policy of the Russian empire in the Steppe Territory (second half of the xix - beginning of the 20th century): to the formulation of the problem. Izvestiya AltSU, No. 4-1 (76). URL: https://cyberleninka.ru/article/n/obrazovatelnaya-politika-rossiyskoy-imperii-vstepnom-krae-vtoraya-polovina-xix-nachalo-xx-vk-postanovke-problemy (date of access: 09/27/2021).

Taukelev, A.N. (1960). Political views of the Kazakh educator Abai Kunanbayev. Scientific notes of the Kazakh State University CM. Kirov. Legal series, vol. 6, 97-99. 
Udartsev, S. F. (2007). Abay Kunanbayev: thinker, judge, legislator. Geniuses of culture: Pushkin and Abay. - Rostov-on-Don-Astana-Armavir, pp. 227-246. https://abai.kaznu.kz/rus/?p=294

Uspanova, K. Zh. (2002). Ideas of folk pedagogy in the development of education and in the work of Kazakh enlighteners during the accession of Kazakhstan to Russia: First half of the 18th - mid-19th centuries (abstract of thesis. ... candidate of pedagogical sciences). Tyumen. state un-t., Tyumen, $25 \mathrm{p}$. https://www.dissercat.com/content/idei-narodnoi-pedagogiki-v-razvitiiobrazovaniya-i-v-tvorchestve-kazakhskikh-prosvetitelei-v

Vorozhbitova, A., Karabulatova, I., Bzegezheva, Z., Druzhinina, V., \& Pyankova, T. (2019). A glossy magazine discourse of the early twenty-first century as a tool of globalization: Sochi school of linguistics and rhetoric. Amazonia Investiga, 8(24), 170-180.

Retrieved https://amazoniainvestiga.info/index.php/amazonia/article/view/969

Wodak, R. (2009). The Discourse-Historical Approach Methods of Critical Discourse Analysis, 2 hd ed. London: Saqe, pp. 63-94.

Zharikbaev, K.B., Kaliev, S.K. (1995). Anthology of pedagogical thought in Kazakhstan. Comp. Almaty: Rauan, 512 p. ISBN 5-625-02758-7 